\title{
Controlled-release and preserved bioactivity of proteins from (self-assembled) core-shell double-walled microspheres [Retraction]
}

Yuan W, Liu Z. Controlled-release and preserved bioactivity of proteins from (self-assembled) core-shell double-walled microspheres. Int J Nanomedicine. 2012;7:257-270.

The Editor-in-Chief and Publisher of the International Journal of Nanomedicine have been alerted to unacceptable levels of image duplication in the published article.

The affected figures within the article presented above are:

- Figure S3 (B) and (C) are duplicates of Figure 2 Panel I (A) and (B);

- Figure 2 Panel I (E) is a duplicate of Panel I (C);

- Figure 2 Panel II (B) and (C) are duplicates of Panel II (A);

- Figure SI Panel II (A) is a duplicate of Figure 2 Panel II (D);
- Figure SI Panel II (C) is a duplicate of Figure 2 Panel II (E);

- Figure $5(\mathrm{~B})$ is a duplicate of $5(\mathrm{~A})$;

- Figure S4 (A) is a duplicate of Figure S1 Panel I (A);

- Figure S4 (B) is a duplicate of Figure SI Panel I (B);

- Figure SI Panel (F) is a duplicate of Panel I (C);

- Figure 1D and F are duplicates of Figure 9A and D, respectively, in paper Yuan W, Zhang Y, Wu F, Li H, Cai Y, Zhang Y, Han M, Jin T. Preparation of proteinloaded sustained-release microspheres via 'solid-in-oilin-hydrophilic oil-in-ethanol (S/O/hO/E)' emulsification. Colloids Surf B Biointerfaces. 2010;79:326-333.

The authors were contacted and were unable to sufficiently explain the irregularities in the images or satisfactorily provide the original images.
International Journal of Nanomedicine

\section{Publish your work in this journal}

The International Journal of Nanomedicine is an international, peerreviewed journal focusing on the application of nanotechnology in diagnostics, therapeutics, and drug delivery systems throughout the biomedical field. This journal is indexed on PubMed Central, MedLine, CAS, SciSearch ${ }^{\circledR}$, Current Contents ${ }^{\circledR} /$ Clinical Medicine,

\section{Dovepress}

Journal Citation Reports/Science Edition, EMBase, Scopus and the Elsevier Bibliographic databases. The manuscript management system is completely online and includes a very quick and fair peer-review system, which is all easy to use. Visit http://www.dovepress.com/ testimonials.php to read real quotes from published authors. 